\title{
Protective and therapeutic effect of Vitex agnus-castus against prostate cancer in rat
}

\author{
Abeer Y. Ibrahim ${ }^{1}$, Samah A. El-Newary ${ }^{1 *}$, Eman R. Youness $^{2}$, Amr M.M. Ibrahim², Walaa A. El Kashak ${ }^{3}$ \\ ${ }^{1}$ Medical Biochemistry Department, Medical Research Division, National Research Centre, Giza, Egypt. \\ ${ }^{2}$ Medicinal and Aromatic Plants Research Department, ${ }^{3}$ Natural Compounds Chemistry Department, Pharmaceutical and Drug Industries Research \\ Division, National Research Centre, Giza, Egypt.
}

\section{ARTICLE INFO}

Article history:

Received on: 06/06/2017

Accepted on: 21/07/2017

Available online: $30 / 12 / 2017$

\section{Key words:}

Prostate cancer; vitex; antiandrogen; $\mathrm{Na}^{+} / \mathrm{K}^{+}$ATPase inhibitors; 5 -a reductase; 7,12-

Dimethylbenz(a)anthracene.

\begin{abstract}
This work was prompted to investigate effect of the vitex berries crude extract on prostate cancer relevant to the cancer growth rate limiting enzymes $\left(5-\alpha\right.$ reductase and $\mathrm{Na}^{+} / \mathrm{K}^{+}$ATPase, tumor biomarker; prostate specific antigen (PSA), carcinoembryonic antigen (CEA), sexual hormones; testosterone and luteinizing hormone, antiinflammatory markers and antioxidant markers. Vitex berries crude extract was prepared and tested against human prostate cancer cell line (PC3) and then incorporated into in-vivo model for prostate cancer induced chemically in rats using chronic administration of testosterone $(3 \mathrm{mg} / \mathrm{kg} / 90$ days $)$ in a sub-cutaneous route and intraperitoneal injection of carcinogenic material, 7,12-Dimethylbenz(a)anthracene (DMBA) at dose of 65 $\mathrm{mg} / \mathrm{kg}$ as a single dose. Vitex extract at dose of $165 \mathrm{mg} / \mathrm{kg} /$ day inhibited cell growth of PC3 which were completely killed at $100 \mu \mathrm{g} / \mathrm{ml}$. In in-vivo study, Vitex extract showed potent anti-prostate cancer evident as significant reduction in cancer growth rate limiting enzymes; 5- $\alpha$ reductase, $\mathrm{Na}^{+} / \mathrm{K}^{+}$ATPase and prostate specific antigen with suppression in carcinoembryonic antigen production, which amplified by prostate cancer induction. A selective anti-inflammatory effect was recorded with vitex administration represented as significant inhibition in cyclooxygenase-2 and non-significant effect on cyclooxygenase-1. It showed ameliorative effects on sexual hormones showed in amendment in testosterone and luteinizing hormone affected by prostate cancer induction. Investigations of this work prove vitex extract has potential role as anti-prostate cancer evaluated by in-vitro and in-vivo protocols. The anti-prostate cancer properties of vitex extract may be due to its effect against cancer risk factors; antioxidant and anti-inflammatory characters, ameliorative effect on sex hormones and suppression in cancer growth rate limiting enzymes.
\end{abstract}

\section{INTRODUCTION}

Cancer stills a main reason of death, though, research is ongoing for the development of greater effective drugs. Many medicinal plants showed possibility to prevent the occurrence and/or development of cancer. Prostate, a male gland, produces fluid that is part of semen. Prostate cancer occurs when the prostate gland cells grows uncontrollably which is considered as adenocarcinomas cancer. Prostate may also attack by else prostate cancer as sarcomas, small cell carcinomas, neuroendocrine tumors (other than small cell carcinomas) and

\footnotetext{
* Corresponding Author

Samah A.El-Newary, Medicinal and Aromatic Plants Research

Department National Research Center, Giza, Egypt.

Email: samahelnewary_@yahoo.com
}

transitional cell carcinomas (American Cancer Society, 2014). No symptom was usually recorded with early prostate cancer but more sophisticated prostate cancers occasionally show symptoms like urination complications like a slow or weak urinary stream or the need to urinate more, especially at night, urine or semen associated with blood, erection trouble, pain in the hips, back, chest. Due to cancer pressing on the spinal cord, patients feel with weakness or numbness in the legs or feet and loss of bladder or bowel control (American Joint Committee on Cancer, 2010). Prostate cancer may be induced by many factors as age, race/ethnicity, geography, history of family, gene change, diet, obesity, smoking, chemical exposure, inflammation of the prostate, sexually transmitted infections and vasectomy (Blume-Peytavi et al., 2008). 5- $\alpha$ reductase inhibitors drugs has been used in treatment of benign prostatic hyperplasia (BPH). 
The daily aspirin intake may reduce the risk of getting and dying from prostate cancer (Blume-Peytavi et al., 2008). 5- $\alpha$ reductase enzyme transfers testosterone into dihydrotestosterone. Dihydrotestosterone has great ability to conjugate with androgen receptors. 5- $\alpha$ reductase inhibitors stop the function of 5- $\alpha$ reductase leading to increment in the concentrations of testosterone and decreasing in the concentrations of dihydrotestosterone. 5- $\alpha$ reductase inhibitors are used in the management of baldness, prostate hyperplasia and prostate cancer (Blume-Peytavi et al., 2008). On the other hand, recent epidemiological studies confirmed the anti-cancer ability of $\mathrm{Na}^{+} / \mathrm{K}^{+}$ATPase inhibitors drugs against prostate, breast, lung cancer or leukemia. The anti-cancer ability of $\mathrm{Na}^{+} / \mathrm{K}^{+}$ATPase inhibitors has also confirmed in multiple preclinical assays and have reached early clinical trials (Alevizopoulos et al., 2014).

The Mediterranean region native plant Vitex agnus castus is a shrub grown to reach height from $1 \mathrm{~m}$ to $5 \mathrm{~m}$. Vitex leaves and berries were documented for medicinal purposes as a part of traditional medicine. Many physicians like Greece physician prefer to use berries of vitex in decreasing the sexual ability so it named chaste tree. Also, it has been referred as monk's pepper because monks have been used it as anti-libido agent to help them to remain chaste. Traditional Chinese medicine in many prescriptions used the extract as helper in uterus circulation with constraint and stagnation and as pain analgesic effector for pain in menstruation as well as for menstruation lack treatment (Ahangarpour et al., 2016).

Commonly, it is used as reproductive system toner, menopause regulator and regulator for sexual ability and menstruation (Chopin Lucks, 2008a). In addition, vitex herb was used for harmonizing the expression of sexually functions. It was reported from clinical researches that vitex extracts have useful effects on female hormonal system also clinical researches characterized some active constituents that are responsible for these effects (Chopin Lucks, 2008b). It was noticed that vitex can inhibits the production of prolactin from lactotroph cells which included in anterior pituitary gland, compounds isolated from vitex play as dopamine antagonists that used in lactotroph receptor cells to obtain the same effect of dopamine and to inhibit the production of prolactin preventing hyperprolactemia. Also, Merz et al. (1996) demonstrated that Vitex agnus-castus with high dose caused a slight decrease on prolactin concentration in blood of healthy men, while the low doses showed opposite observation, in the same experiment. It was believed that the prolactin reduction influence Follicle-stimulating hormone and estrogen levels in women as well as testosterone levels in men.

From 1941 Huggins and Hodges reported that the increase in testosterone levels of the men blood increased the risk of prostate cancer (Klap et al., 2015). Also, Ahmed et al., 2008 confirmed the same results and reported the positive relationship between elevated levels of testosterone and prostate cancer propagation. Contrary, other researchers found that no relationship was noticed between prostate cancer and testosterone (Morgentaler and Rhoden, 2006). Hence, optimal level of the testosterone is required to the health of prostate. Goetz, 2009 found the effeteness of Vitex agnus-castus in prostate disorders. This mentioned action is important to resolve prostate disorders, menstrual complains, menopause problems and infertility (Ahangarpour et al., 2016).

Through these reported activities of vitex on sex hormones, this research was planned to study the impact of vitex extract on prostate cancer induced chemically in rats considering related hormones and enzymes that may control the progression of cancer.

\section{MATERIALS AND METHODS}

\section{Plant material and extraction}

Berries of Vitex agnus-castus were collected from the organic farm of SEKEM company group. Sample was authenticated by Orman botanical Garden, Giza, Egypt. A voucher specimen is deposited in the herbarium of Orman botanical Garden, Agricultural Research Centre, Giza, Egypt. Berries were exhaustively extracted by hydroalcohol (80\%). The extract was concentrated under reduced pressure and then it was lyophilized to be free from any water or solvents. The powder was then incorporated into the bio-assay.

\section{Chemicals}

Testosterone and 7,12-Dimethylbenz(a)anthracene (DMBA) purchased from Sigma Aldrich, USA. Ethylene diamine tetra acetate (EDTA), Sodium dihydrogen phosphate, disodium monohydrogen phosphate were purchased from Fin Chem Ltd. Liver, kidney and lipid profile kits were obtained from Bio diagnostic, Egypt. ELISA kits for testosterone and Leutinizing hormone, $\mathrm{Na}^{+} / \mathrm{K}^{+}$ATPase, 5- $\alpha$ reductase, Prostate specific antigen, carcinoembryonic antigen, cyclooxygenases activity, were purchased from Sunlong Biotech Co. Ltd., Zhejiang, China. Antioxidant parameters kits were purchased from Bio diagnostic, Egypt.

\section{In vitro anti-prostate cancer using cell line assay}

Cell viability of human prostate cancer (PC3) were assessed by the mitochondrial dependent reduction of yellow MTT (3-(4,5-dimethylthiazol-2-yl)-2,5-diphenyl tetrazolium bromide) to purple formazan (Mosmann, 1983). All the following procedures were done in a sterile area using a Laminar flow cabinet biosafety class II level (Baker, SG403INT, Sanford, ME, USA). Cells were suspended in RPMI 1640 medium (PC3), 1\% antibioticantimycotic mixture $(10,000 \mathrm{U} / \mathrm{ml}$ Potassium Penicillin, $10,000 \mu \mathrm{g} / \mathrm{ml}$ Streptomycin Sulfate and $25 \mu \mathrm{g} / \mathrm{ml}$ Amphotericin B) and $1 \%$ L-glutamine at $37{ }^{\circ} \mathrm{C}$ under $5 \% \mathrm{CO}_{2}$. Cells were batch cultured for 10 days, then seeded at concentration of $10 \times 10^{3}$ cells/well in fresh complete growth medium in 96-well microtiter plastic plates at $37{ }^{\circ} \mathrm{C}$ for $24 \mathrm{~h}$ under $5 \% \mathrm{CO}_{2}$ using a water jacketed Carbon dioxide incubator (Sheldon, TC2323, Cornelius, OR, USA). Media was aspirated, fresh medium (without serum) was added and cells were incubated either alone (negative control) or with different concentration of sample to give a final 
concentration of (100-50-25-12.5-6.25-3.125 and $1.56 \mu \mathrm{g} / \mathrm{ml})$. After $48 \mathrm{~h}$ of incubation, the medium was aspirated, 40ul MTT salt $(2.5 \mu \mathrm{g} / \mathrm{ml})$ were added to each well and incubated for a further four hours at $37^{\circ} \mathrm{C}$ under $5 \% \mathrm{CO}_{2}$. To stop the reaction and dissolving the formed crystals, $200 \mu \mathrm{L}$ of $10 \%$ Sodium dodecyl sulphate (SDS) in deionized water was added to each well and incubated overnight at $37^{\circ} \mathrm{C}$. A positive control which composed of $100 \mu \mathrm{g} / \mathrm{ml}$ was used as a known cytotoxic natural agent who gives $100 \%$ lethality under the same conditions (Thabrew et al., 1997; El-Menshawi et al., 2010). The absorbance was then measured using a microplate multi-well reader (Bio-Rad Laboratories Inc., model 3350, Hercules, California, USA) at $595 \mathrm{~nm}$ and a reference wavelength of $620 \mathrm{~nm}$. A statistical significance was tested between samples and negative control (cells with vehicle) using independent t-test by SPSS 11 program. DMSO is the vehicle used for dissolution of plant extracts and its final concentration on the cells was less than $0.2 \%$. The percentage of change in viability was calculated according to the formula:

(Reading of extract / Reading of negative control) -1) x 100

\section{In-vivo anti-prostate cancer study Ethical issues}

This research protocol was permitted by National Research Centre Medical Ethics committee, Egypt, as a part of the project entitled "New drug discovery for breast and prostate cancers from Egyptian medicinal plants and polysaccharides derived from natural sources" with registration No 6/014.

\section{Acute toxicity study}

The acute toxicity study (Bruce, 1985) was performed using mice (20-25g), each group contains 8 animals, with dose patron started from $500 \mathrm{mg} / \mathrm{Kg}$ body weight up to $3500 \mathrm{mg} / \mathrm{kg}$ body weight. The dose of the extract which killed $50 \%$ of animals was $2000 \mathrm{mg} / \mathrm{kg}$ body weight. $\mathrm{LD}_{50}$ of the extract was calculated using BioStat program (BioStat 2009 Build 5.8.4.3) and it was recorded at $1650 \mathrm{mg} / \mathrm{kg}$ body weight. Therefore, the selected dose to study the in-vivo anti-prostate cancer activity of vitex crude extract was $165 \mathrm{mg} / \mathrm{kg}$ body weight/ day as the tenth of the $\mathrm{LD}_{50}$ (Garg et al., 2016; Ghosh, 1984).

\section{Animals}

One hundred fifty adult male Spargue Dawley rats weighing between 130-150 g, 90 days old, obtained from animal house of National Research Centre, were maintained under laboratory facilities and look after in standard polypropylene cages at room temperature of $25-30^{\circ} \mathrm{C}, 60$ to $65 \%$ relative humidity and suppled with standard diet and water ad libitum. The diurnal lighting and darkness cycle is $12 \mathrm{~h}$.

\section{Experimental layout}

After acclimation for two weeks, animals were randomly divided into three main groups. The first main group was a negative control group, which were administered saline only at all the experimental period ( $\mathrm{n}=30 \mathrm{rat})$. The second main group was positive one that includes two subgroups; animals administered vitex berries crude extract at $165 \mathrm{mg} / \mathrm{kg}$ body weight orally for three months $(n=30)$, while the second subgroup was testosterone subgroup which were chronically administered testosterone at $3 \mathrm{mg} / \mathrm{kg}$ body weight for 90 days in subcutaneous route as tumor promoter and prostate hyperplasia promoter following administration of carcinogenic material, 7,12-Dimethylbenz(a) anthracene cancer promoter at $65 \mathrm{mg} / \mathrm{kg}$ in an intraperitoneal route dissolved in sesame oil and saline in an equal percentage and then maintained to lab condition until the end of experiment $(n=30$ rats).

The third main group was treated group which include two subgroups; the first was therapeutic subgroup administered testosterone at $3 \mathrm{mg} / \mathrm{kg}$ body weight/ 90 days as subcutaneous route after intraperitoneal administration of carcinogenic material, 7,12-Dimethylbenz(a)anthracene at $65 \mathrm{mg} / \mathrm{kg}$ and then treated with vitex at $165 \mathrm{mg} / \mathrm{kg} /$ three months $(\mathrm{n}=30)$ while the second subgroup was protective subgroup administered vitex at $165 \mathrm{mg} /$ $\mathrm{kg} /$ three months and then treated with testosterone at $3 \mathrm{mg} / \mathrm{kg}$ body weight for 90 days as subcutaneous route after intraperitoneal administration of carcinogenic material, 7,12Dimethylbenz(a)anthraceneat $65 \mathrm{mg} / \mathrm{Kg}$ dissolved in sesame oil and saline in an equal percentage, protective tested group $(n=30)$. After chronic administration of testosterone and carcinogenic material for therapeutic treatment, animals blood sample were collected from lateral tail vein to determine prostate specific antigen (PSA) as specific prostate cancer biomarker detector (Leonard et al., 2010). Considering PSA data, cancer was induced in $67 \%$ of treated animals $(n=20)$ by the way used in chemical cancer induction.

Animals reach more than 20ng/ ml PSA was considered as prostate adenocarcinoma animals and used for the treatment (Bosland, 1992).

At the end of the experiment (6 months), animals were fasted for 18 hours and then were anesthetized and blood samples were collected from retro orbital plexus and then centrifuged at 4000rpm for 10min using Sigma labor zentrifugen. Organs were collected and weighed for chronic toxicity evaluation.

\section{Biochemical analysis}

Serum samples were used for multi assessment branches, toxicity biomarkers including antioxidant enzyme activities and liver \& kidney functions, anti-inflammatory biomarker enzymes activities and tumor biomarker, carcinoembryonic antigen (CEA) and prostate specific antigen (PSA).

liver function and total protein; aspartate aminotransferase (AST) and alanine aminotransferase (ALT) were spectrophotometrically assessed in serum according to Henry (1964) and Reitman and Frankel (1957).Total lipids and total cholesterol were determined based on the methods of Estadella et al.(2004) and Allain et al.(1974). Kidney function; urea, uric acid and creatinine were estimated spectrophotometrically in serum as methods described by Tabacco et al.(1979), Gochman and Schmitz (1971), and Faulkner and King (1976), respectively. 
Rate limiting factors for prostate sufficient work including testosterone and luteinizing hormones levels while 5- $\alpha$ reductase activity as well as prostate cell metabolism and growth marker, a1- $\mathrm{Na}^{+} / \mathrm{K}^{+}$ATPase were determined in prostate homogenate prepared in using ELISA kits of Sunlong Biotech Co., LTD. Hormones levels were determined at the half time of curative period (45 days) and at the end of experiment as a part of animal following up. Glutathione (GSH) concentration was determined spectrophotometrically according to the method of Griffith (1980). Antioxidants and enzyme activities; glutathione reductase (GR), glutathione S-transferase (GST), Glutathione peroxidase (GPx), and catalase (CAT) were determined according to the methods of Goldberg and Spooner (1983), Paglia and Valentine (1967), Habig et al.(1974), and Beers and Sizer (1952), respectively.

\section{RESULTS}

\section{In-vitro anti-prostate cancer using cell line}

The Cell viability assay was used to determine the cytotoxic effect of Vitex berries crude extract on prostate cancer cell line (PC3) which was assessed by mitochondrial dependent reduction of yellow MTT to purple formazan. Vitex extract showed high anti-cancer effect against PC3 and completely kill all cell at $100 \mu \mathrm{g} / \mathrm{ml}$. Vitex extract exhibited low $\mathrm{IC}_{50} 6.90 \mu \mathrm{g} / \mathrm{ml}$ whereas $\mathrm{IC}_{90}$ was $14.40 \mu \mathrm{g} / \mathrm{ml}$.
There is no depletive effect was recorded when animals administered vitex extract as the positive control groups. In comparison with the negative control group. Induction of prostate cancer using chronic administration of testosterone as prostate tumor promoter following administration of carcinogenic material (DMBA) caused remarkable enlargement in liver $(6.71 \pm 1.01 \mathrm{~g} / 100$ $\mathrm{g})$, prostate $(1.41 \pm 0.12 \mathrm{~g} / 100 \mathrm{~g})$, brain $(0.90 \pm 0.26 \mathrm{~g} / 100 \mathrm{~g})$ and spleen $(0.72 \pm 0.31 \mathrm{~g} / 100 \mathrm{~g})$ concurrence with significant shrinking in heart $(0.90 \pm 0.31 \mathrm{~g} / 100 \mathrm{~g})$ and $\operatorname{lung}(0.53 \pm 0.09 \mathrm{~g} / 100 \mathrm{~g})$, while vitex extract either protective or therapeutic agent significantly reduced the regression effect of carcinogenic material so organs exhibited better record values than cancer group $(P<0.05)$. Therefore, the shrinking observed for heart and lung was disappeared also the enlargement in liver, brain, spleen and prostate gland have to be near to the negative control group as mentioned in Table (1). No significant differences were noticed between protective and therapeutic effect of vitex extract on organs weights meanwhile, therapeutic treatment of vitex extract was more promising than the protective treatment.

As a part of vitex extract chronic toxicity evaluation, liver and kidney functions were estimated. Vitex berries crude extract produced a recovering effect on liver function on the recorded remarkable disturbance produced by cancer induction. Induction of prostate cancer amplify total protein and liver enzyme levels $(15.64 \mathrm{mg} / \mathrm{dl}$ for total protein, $300 \mathrm{U} / \mathrm{l}$ for AST and $110 \mathrm{U} / 1$ for ALT) as compared to the negative control (Figure1).

Table 1: Effect of Vitex aguns-castus on vital organs of normal and cancer rats, chronic toxicity effect through 90 days.

\begin{tabular}{|c|c|c|c|c|c|c|c|c|c|}
\hline \multirow{2}{*}{ Main groups } & \multirow{2}{*}{ subgroup } & \multicolumn{8}{|c|}{ Organs weight as g/ $100 \mathrm{~g}$} \\
\hline & & Liver & Kidnev & Spleen & Lung & Brain & Heart & Testis & Prostate \\
\hline Negative group & -ve control & $4.25 \pm 1.00^{\mathrm{a}}$ & $1.15 \pm 0.41$ & $0.47 \pm 0.12$ & $0.73 \pm 0.18^{\mathrm{c}}$ & $0.40 \pm 0.14^{\mathrm{c}}$ & $1.22 \pm 0.48^{\mathrm{c}}$ & $1.20 \pm 0.91^{\mathrm{c}}$ & $0.36 \pm 0.20^{\mathrm{c}}$ \\
\hline \multirow{2}{*}{ Positive groups } & Vitex $\left({ }^{+}\right.$ve $)$ & $4.27 \pm 0.95^{\mathrm{a}}$ & $1.05 \pm 0.37^{\mathrm{a}}$ & $0.50 \pm 0.10$ & $0.70 \pm 0.37^{\mathrm{c}}$ & $0.40 \pm 0.13^{\mathrm{c}}$ & $1.24 \pm 0.32^{\mathrm{c}}$ & $1.21 \pm 0.78^{c}$ & $0.36 \pm 0.10^{\mathrm{c}}$ \\
\hline & Cancer group & $6.71 \pm 1.01$ & $1.08 \pm 0.56^{\mathrm{a}}$ & $0.72 \pm 0.31$ & $0.53 \pm 0.09$ & $0.90 \pm 0.26$ & $0.90 \pm 0.31$ & $1.31 \pm 0.58$ & $1.41 \pm 0.12$ \\
\hline \multirow{2}{*}{ Treated group } & Protective & $3.94 \pm 0.94$ & $0.86 \pm 0.42^{\mathrm{c}}$ & $0.61 \pm 0.24$ & $0.89 \pm 0.22$ & $0.52 \pm 0.21$ & $1.21 \pm 0.70^{\mathrm{c}}$ & $1.08 \pm 0.93$ & $0.75 \pm 0.31$ \\
\hline & Therapeutic & $3.84 \pm 0.28$ & $0.89 \pm 0.33^{c}$ & $0.28 \pm 0.1$ & $0.78 \pm 0.31$ & $0.40 \pm 0.11$ & $1.13 \pm 0.18$ & $0.89 \pm 0.28$ & $0.49 \pm 0.22$ \\
\hline
\end{tabular}

letters means non-significant difference between that have the same letter as compared to - ve controls. $P<0.05$.

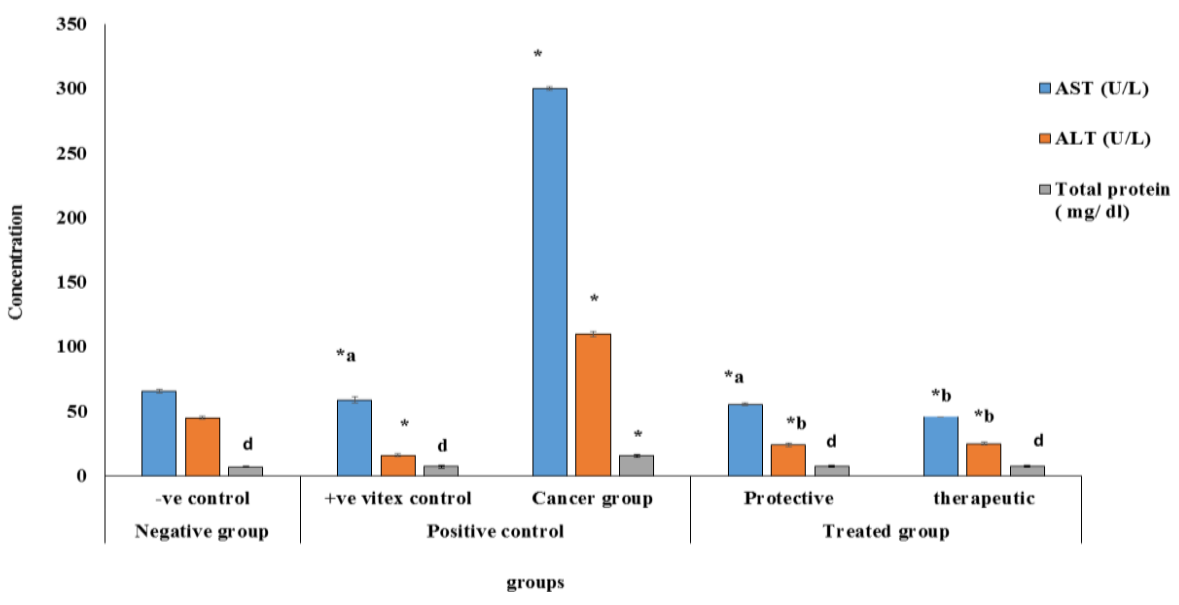

Fig. 1: Effect of Vitex agnus-castus extract on liver functions in affected rats.

- The presented data are mean of 20 replicates \pm SD.

- $\quad$ Data were analyzed using ANOVA one-way followed with post hoc for multiple comparisons and $P<0.05$.

- $\quad$ Appearance of * means significant difference between groups and -ve controls while appearance of letters means no significant difference between groups that have the same letter as compared to -ve controls. 
In comparison with cancer control, vitex extract administration exhibited hepatoprotective properties expounded as significant diminishing on these parameters in each treatment, protective or therapeutic groups $(P<0.05)$. Prostate cancer induction caused significant increment on uric acid, urea and creatinine $(5.11 \pm 0.92, \quad 18.41 \pm 1.06$ and $8.15 \pm 1.24 \mathrm{mg} / \mathrm{dl}$, respectively) in consideration with the negative control as represented in (Figure 2) $(P<0.05)$.

Oppositely, kidney performance was protected when animals co-administrated vitex extract. Similarly, vitex extract showed therapeutic effect in kidney functions represented as significant reduction on kidney function markers compared to cancer control. There are no significant differences were noticed between the protective and therapeutic effect of vitex extract in this concern.

As a part of toxicity evaluation, total lipid and total cholesterol were determined (Figure 3). Cancer induction induced total lipid and total cholesterol to reach high values $(186.32 \mathrm{mg} / \mathrm{dl}$ $7.44 \mathrm{mmol} / \mathrm{l})$ with significant rise determined as 167.55 and $238.30 \%$ compared to the negative control), $P<0.05$. On the other hand, receiving vitex extract significantly decreased the lipid level and cholesterol content of protective and therapeutic groups comparable to cancer the positive control. In the positive vitex control, total cholesterol did not affect significantly.

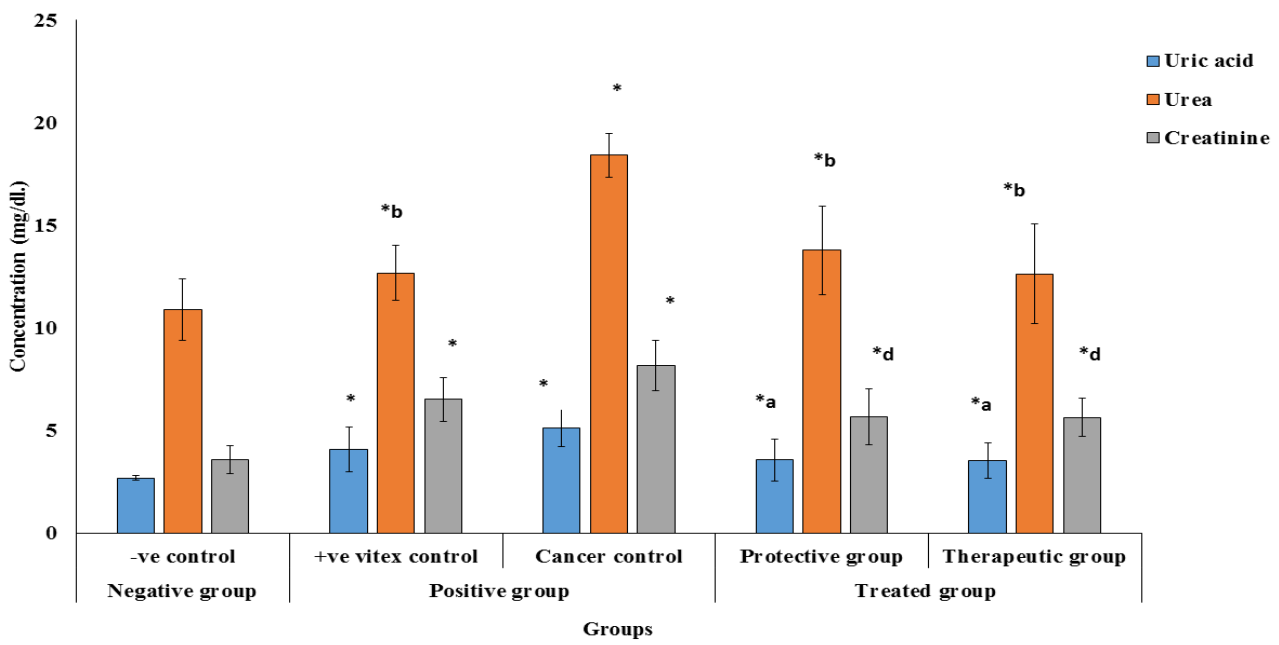

Fig. 2: Effect of Vitex agnus-castus extract on kidney function in vehicle and affected rats

- $\quad$ The presented data are mean of 20 replicates \pm SE.

- Data were analyzed using ANOVA one-way followed with post hoc for multiple comparisons and $P<0.05$.

- $\quad$ Appearance of $*$ means significant difference between groups and -ve controls while appearance of letters means non-significant difference between groups that have the same letter as compared to -ve controls.

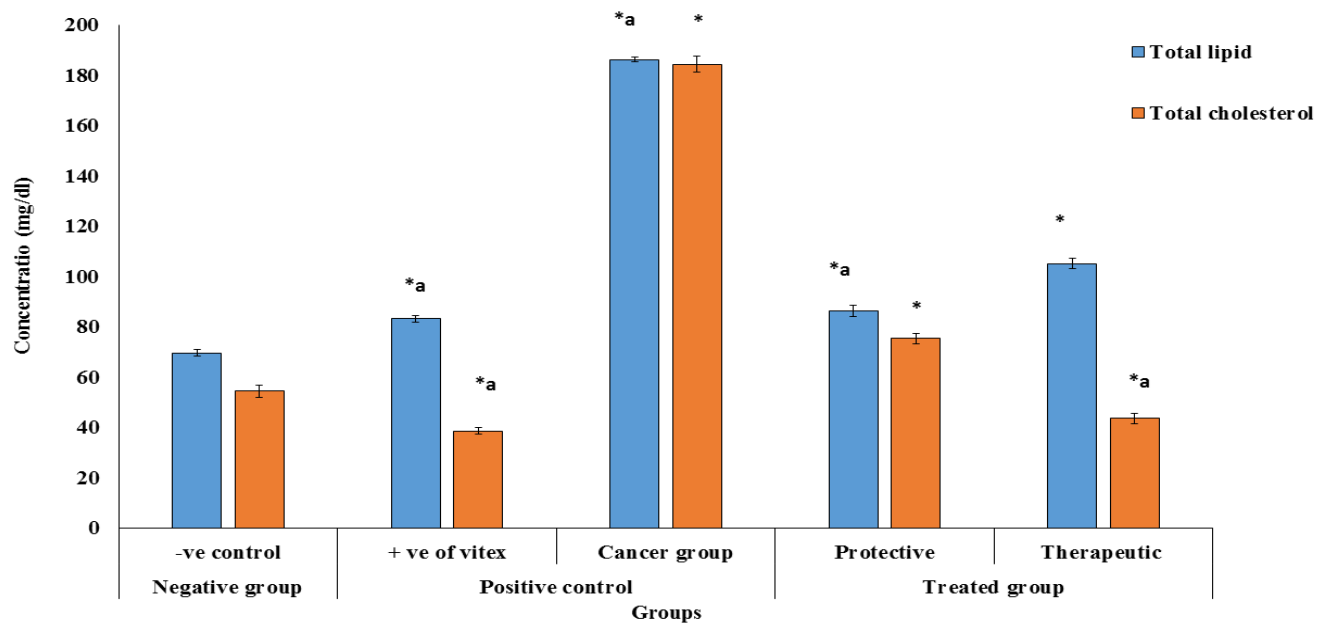

Fig. 3: Impact of Vitex agnus-castus extract on total lipid and total cholesterol in Prostate cancer in male rat

- $\quad$ The presented data are mean of 20 replicates \pm SE.

- Data were analyzed using ANOVA one-way followed with post hoc for multiple comparisons and $P<0.05$.

- $\quad$ Appearance of * means significant difference between groups and -ve controls while appearance of letters means non-significantdifference between groups that have the same letter as compared to -ve controls. 
Table 2: Impact of Vitex agnus-castus berries extract on hormonal status of male rats in prostate cancer model.

\begin{tabular}{|c|c|c|c|c|c|}
\hline \multirow[b]{2}{*}{ Group } & \multirow[t]{2}{*}{ Parameter } & \multicolumn{2}{|c|}{ Testosterone $(\mu \mathrm{g} / \mathrm{ml})$} & \multicolumn{2}{|c|}{ Leutinizing hormone(ng/ml) } \\
\hline & & After 45 days & After 90 days & After 45 days & After 90 days \\
\hline Negative control group & -ve control & $0.31 \pm 0.09$ & $0.30 \pm 0.05$ & $37.15 \pm 0.68$ & $38 \pm 2.11$ \\
\hline \multirow[t]{2}{*}{ Positive control group } & +ve of Vitex & $0.20 \pm 0.05^{\mathrm{a}}$ & $0.18 \pm 0.02^{b}$ & $24.37 \pm 1.12^{\mathrm{c}}$ & $20.48 \pm 1.23^{\mathrm{d}}$ \\
\hline & cancer control & $0.20 \pm 0.04^{\mathrm{a}}$ & $0.10 \pm 0.03$ & $36.56 \pm 1.00$ & $28.00 \pm 2.61$ \\
\hline \multirow[t]{2}{*}{ Treated group } & Protective & $0.21 \pm 0.04^{\mathrm{a}}$ & $0.17 \pm 0.05^{\mathrm{b}}$ & $23.25 \pm 2.1^{\mathrm{c}}$ & $20.53 \pm 1.48^{\mathrm{d}}$ \\
\hline & Therapeutic & $0.24 \pm 0.01$ & $0.22 \pm 0.06$ & $25.59 \pm 1.64^{\mathrm{c}}$ & $22.48 \pm 0.98$ \\
\hline
\end{tabular}

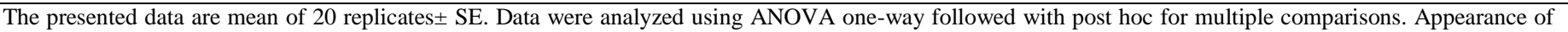
letters means non-significant difference between that have the same letter as compared to cancer controls. $P<0.05$.

Table 3: Cancer rate limiting enzymes as treated with Vitex agnus-castus extract.

\begin{tabular}{|c|c|c|c|c|c|}
\hline Main Groups & Subgroups & $\begin{array}{c}\text { Steroid 5- } \alpha \text { reductase } \\
(\mu \mathrm{g} \mathrm{Eq} / \mathrm{ml})\end{array}$ & $\begin{array}{c}\text { a1-Na }{ }^{+} / \mathrm{K}^{+} \text {ATPase } \\
(\mu \mathrm{g} \mathrm{Eq} / \mathrm{ml})\end{array}$ & $\begin{array}{c}\text { Prostate specific antigen } \\
(\mathrm{ng} / \mathrm{ml})\end{array}$ & $\begin{array}{c}\text { Carcinoembryonic antigen } \\
(\text { CEA })(\mu \mathrm{g} \mathrm{Eq} / \mathrm{ml})\end{array}$ \\
\hline Negative group & -ve control & $49.53 \pm 1.68$ & $0.89 \pm 0.05$ & $4.00 \pm 1.03^{f}$ & $296.25 \pm 2.58^{\mathrm{a}}$ \\
\hline Positive group & $\begin{array}{l}\text { +ve of Vitex } \\
\text { Cancer control }\end{array}$ & $\begin{array}{l}18.18 \pm 1.00^{*} \\
69.78 \pm 1.54^{*}\end{array}$ & $\begin{array}{l}0.34 \pm 0.12 * \mathrm{a} \\
0.61 \pm 0.89 *\end{array}$ & $\begin{array}{l}4.11 \pm 1.51^{\mathrm{f}} \\
85.23 \pm 2.84\end{array}$ & $\begin{array}{l}290.46 \pm 3.12^{\mathrm{a}} \\
808.8 \pm 2.74^{*}\end{array}$ \\
\hline Treated group & $\begin{array}{l}\text { Protective } \\
\text { Therapeutic }\end{array}$ & $\begin{array}{l}30.81 \pm 2.11^{*} \\
24.94 \pm 0.97 *\end{array}$ & $\begin{array}{c}0.30 \pm 0.08^{* \mathrm{a}} \\
0.27 \pm 0.06^{*}\end{array}$ & $\begin{array}{l}26.54 \pm 2.37 \\
15.34 \pm 2.43\end{array}$ & $\begin{array}{l}461.84 \pm 1.68^{*} \\
196.19 \pm 2.11^{*}\end{array}$ \\
\hline
\end{tabular}

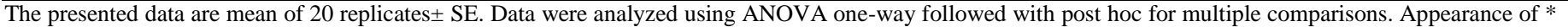

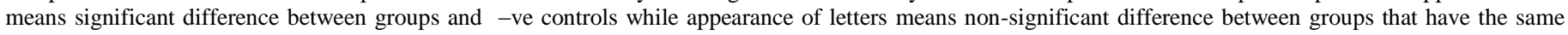
letter as compared to cancer controls. $P<0.05$.

\section{Sex-Hormone status of induced prostate cancer male rats and vitex treated animals}

Testosterone and leutinizing hormone levels were determined using ELISA kits as a performance of anti-androgen activity of vitex. Prostate cancer reduced both of testosterone and luteinizing hormone. After 45 days of induction of prostate cancer, testosterone was significantly declined to $0.20 \pm 0.04 \mu \mathrm{g} / \mathrm{ml}$ and was continued in decrease after 90 days $(0.10 \pm 0.03 \mu \mathrm{g} / \mathrm{ml})$ taking the negative control into consideration (Table 2). In an opposite manner, application of Vitex crude extract to cancer rats recorded protective effect. It significantly induced testosterone level after 45 and 90 days by $0.21 \pm 0.04$ and $0.17 \pm 0.05 \mu \mathrm{g} / \mathrm{ml}$, respectively) with respect to cancer control animals. Additionally, vitex extract appeared therapeutic characters evident as significant increment in testosterone level after 90 days $(0.22 \pm 0.06 \mu \mathrm{g} / \mathrm{ml})$ in comparison with cancer controls. The therapeutic effect of vitex was better than its protective effect.

A depletive effect was appeared on leutinizing hormone concurrent with induction of prostate cancer and was continued with vitex treatment. In the positive vitex control, vitex, the shaste tree, caused significant diminishing on testosterone and luteinizing hormone continued to 90 days, compared to the negative control.

\section{Effect of vitex berries extract on rate limiting enzymes and tumor biomarker (CEA)}

Recently, many investigations demonstrated the important role of $\alpha-1 \mathrm{Na}^{+} / \mathrm{K}^{+}$ATPase in the organizing of cell functions. The product of $\mathrm{Na}^{+} / \mathrm{K}^{+}$ATPase efficacy is gradient that expedite Compounds uptake through cell membrane which are needed for cell proliferation and growth. $\mathrm{Na}^{+} / \mathrm{K}^{+}$ATPase inhibitors have cytotoxicity to many cancers. This toxicity is dependently sensitive to the used dose. The suggested role of $\mathrm{Na}^{+} / \mathrm{K}^{+}$ATPase inhibitors in prostate cancer cell is inhibition of a1-subunit so it consequently suppresses proliferation and migration of cancer cell and reduce metastasis of tumor (Chen et al., 2014). Therefore, this work plan targeted to determine $\alpha-1 \mathrm{Na}^{+} / \mathrm{K}^{+}$ATPase in prostate cell comparatively in case of normal and induced cancer rats.

Our findings may explain the role of vitex in preventing the development of prostate cancer cells where a great amount of $\mathrm{Na}+\mathrm{K}+$ ATPase is composed in the plasma membrane (Table 3), $P<0.05$. In cancer control, $\mathrm{Na}^{+} / \mathrm{K}^{+}$ATPase was significantly declined by $0.61 \pm 0.89 \mu \mathrm{g} \mathrm{Eq} / \mathrm{ml}$ in comparison with the negative control; $0.89 \pm 0.05 \mu \mathrm{g} \mathrm{Eq} / \mathrm{ml}$. On the other hand, Vitex berries extract produced a significant depletion on $\mathrm{Na}^{+} / \mathrm{K}^{+}$ATPase of protective or therapeutic groups by about $0.30 \pm 0.08$ and $0.27 \pm 0.06$ $\mu \mathrm{g} \mathrm{Eq} / \mathrm{ml}$, respectively, determined in tissue of prostate gland comparable to cancer control.

In addition, steroid 5- $\alpha$ reductase was significantly affected by induction of prostate cancer and was magnified to $69.78 \pm 1.54 \mu \mathrm{g} \mathrm{Eq} / \mathrm{ml}$ with respect to the negative control; $49.53 \pm 1.68 \mu \mathrm{gEq} / \mathrm{ml}$ (Table 6$), P<0.05$. Steroid $5-\alpha$ reductase of animals treated with vitex extract was significantly curtailed to $30.81 \pm 2.11$ and $24.94 \pm 0.97 \mu \mathrm{gEq} / \mathrm{ml}$ in protective and therapeutic groups, respectively, as compared to $69.78 \pm 1.54 \mu \mathrm{g} \mathrm{Eq} / \mathrm{ml}$ for cancer induced animals.

Prostate specific antigen, member of serine proteases, is a prostate product produced in normal and cancer cells (Lilja, 1985). It was approved in 1986 by United States Food and Drug Administration (FDA) for monitoring prostate cancer and then for detection of cancer in 1994. Early cancer detection facilitate using effective therapeutics to patient which consequently can make great decrease in overall death rate.

Induction of prostate cancer lead to significant increment in PSA concentration to reach twenty-one fold in cancer control versus the negative control $(85.23 \pm 2.84$ and $4.00 \pm 1.03 \mathrm{ng} / \mathrm{ml}$ respectively) as data in (Table 3). A significant reduction in PSA concentration was recorded when animals administrated vitex 
extract to reach $26.54 \pm 2.37$ and $15.34 \pm 2.43 \mathrm{ng} / \mathrm{ml}$ for protective and therapeutic groups, respectively, comparing to cancer control $(P<0.05)$.

Also, PSA is used as a detector for prostate cancer, it is not accurate specific and sensitive detector for prostate cancer (Nogueira et al., 2009). Therefore, to make sure about the anticancer properties of vitex crude extract CEA was also used as a cancer biomarker for monitoring anti-cancer effect of vitex in animal model

Carcinoembryonic antigen, membrane-associated glycoprotein, is an oncofetal glycoprotein that expressed in normal mucosal gastrointestinal cells and other tissues like prostate and breast but it over expressed in adenocarcinoma cancer as gastrointestinal adenocarcinoma and prostate adenocarcinoma without expecting that affect survival of patient (Juang et al., 2014). Through this foundation, this study aimed to determine the serum level of CEA in animals of control, vehicle control and two types of treated animals.

Data presented in Table (3) showed that, CEA was significantly magnified to $808.80 \pm 2.74 \mu \mathrm{g} \mathrm{Eq} / \mathrm{ml}$ as a response to prostate cancer induction with respect to the negative control $(296.25 \pm 2.58 \mu \mathrm{g} \mathrm{Eq} / \mathrm{ml})$. CEA concentration of vitex extract treated animals either as protective or as therapeutic agent was significantly declined to $461.84 \pm 1.68$ and $196.19 \mu \mathrm{gEq} / \mathrm{ml}$, respectively, compared to cancer control. Vitex extract showed therapeutic effect, produced CEA lower than that of the negative control.

\section{Influence of vitex on Cyclooxygenases in male sera}

In cancer, cyclooxygenase inhibitors showed considerable role in anticancer therapeutics. Nevertheless, the use of non-steroidal anti-inflammatory drugs as COX-2 inhibitors has adverse effects; thus, discovering natural anti-COX 2 could be a necessary for cancer management. Many investigations confirmed the direct relation between over production of COX-2 and prostate tumor development and angiogenesis (Pruthi et al., 2003). At the end of experiment, COX-1 and COX-2 were assessed in sera samples as mentioned in Table (4). Prostate cancer induction proceeded significant suppression in COX-1 (-30.19\%) accompanied with significant increment on COX-2 (+23.95\%) as compared to the negative control. Oppositely, Vitex extract appeared anti-inflammatory activity when it was used as protective or therapeutic agent, represented as significant augment on COX-1 to reach $0.46 \pm 0.10$ and $0.54 \pm 0.02 \mu \mathrm{g} \mathrm{Eq} / \mathrm{ml}$, respectively, concurrence with significant reduction on COX-2 $(152.38 \pm 2.31$ and $161.57 \pm 1.85 \mu \mathrm{g} \mathrm{Eq} / \mathrm{ml}$ ) with respect to cancer control. Vitex showed ameliorative effect on COX-1 and COX-2, they were adjusted by vitex treatment. The protective application reinforced animal's ability to force cancer through inhibiting inflammatory progression, COX-2 inhibitors.

\section{Antioxidant activity of vitex extract relevant to Glutathione anti- oxidant system}

One of most abundant mechanism for treating many diseases like Alzheimer's, cancer, aging ....etc, is decreasing the oxidative stress as one of the disease risk factors. Sera samples of control animals, vehicle and treated animals were evaluated for their oxidant status (Table 5). Administration of vitex berries crude extract showed a recovering effect on oxidative stress status. A remarkable decrease in GSH by prostate cancer $(0.99 \pm 0.10 \mathrm{mg} /$ dl) was observed while it was significantly protected when animals treated with vitex and recorded an enhancement in therapeutic group $(6.88 \pm 1.04$ and $7.99 \pm 1.13 \mathrm{mg} / \mathrm{dl}$ for protective and therapeutic groups, respectively) compared to cancer control.

Table 4: Rat inflammatory rate limiting enzymes as affected by cancer induction and treated with vitex berries extract.

\begin{tabular}{|c|c|c|c|c|c|}
\hline \multirow[b]{2}{*}{ Parameter } & \multirow{2}{*}{$\begin{array}{l}\text { Negative group } \\
\text {-ve control }\end{array}$} & \multicolumn{2}{|c|}{ Positive control } & \multicolumn{2}{|c|}{ Treated group } \\
\hline & & ${ }^{+}$ve vitex & Cancer control & Protective & Therapeutic \\
\hline COX-1 $(\mu \mathrm{g} \mathrm{Eq} / \mathrm{ml})$ & $0.53 \pm 0.03^{\mathrm{a}}$ & $0.51 \pm 0.03$ & $0.37 \pm 0.02 *$ & $0.46 \pm 0.10^{*}$ & $0.54 \pm 0.02^{\mathrm{a}}$ \\
\hline $\mathrm{COX}-2(\mu \mathrm{g} \mathrm{Eq} / \mathrm{ml})$ & $171.76 \pm 2.13$ & $184.16 \pm 1.97 *$ & $212.90 \pm 2.46^{*}$ & $152.38 \pm 2.31^{* b}$ & $161.57 \pm 1.85^{* \mathrm{~b}}$ \\
\hline
\end{tabular}

Table 5: Antioxidant status of induced prostate cancer animals and animals treated with Vitex berries extract.

\begin{tabular}{|c|c|c|c|c|c|c|}
\hline Group & Parameter & $\begin{array}{c}\text { GSH } \\
\text { concentration } \\
(\mathbf{m g} / \mathbf{d l})\end{array}$ & $\begin{array}{c}\text { GR } \\
(\mu \mathrm{mol} / \mathrm{mg} \\
\text { protein } / \mathrm{min})\end{array}$ & $\begin{array}{c}\text { GST } \\
(\mu \mathrm{mol} / \mathrm{mg} \\
\text { protein/min })\end{array}$ & $\begin{array}{c}\text { GPx } \\
(\mu \mathrm{mol} / \mathrm{mg} \\
\text { protein } / \mathrm{min})\end{array}$ & $\begin{array}{c}\mathrm{CAT}(\mu \mathrm{mol} / \mathrm{mg} \\
\text { protein } / \mathrm{min})\end{array}$ \\
\hline -ve control & & $5.83 \pm 1.21^{\mathrm{a}}$ & $7.19 \pm 2.14$ & $4.86 \pm 0.99^{\mathrm{a}}$ & $2.94 \pm 0.33$ & $19.90 \pm 1.37$ \\
\hline Positive control & $\begin{array}{l}{ }^{+\mathrm{v}} \mathrm{e} \text { Vitex } \\
\text { Cancer group }\end{array}$ & $\begin{array}{l}6.69 \pm 1.07^{\mathrm{a}} \\
0.99 \pm 0.10^{*}\end{array}$ & $\begin{array}{c}8.24 \pm 1.24^{*} \text { a } \\
1.22 \pm 0.95^{*}\end{array}$ & $\begin{array}{l}5.05 \pm 0.85^{*} \\
0.35 \pm 0.07^{*}\end{array}$ & $\begin{array}{l}3.36 \pm 0.41^{\mathrm{a}} \\
0.49 \pm 0.14^{*}\end{array}$ & $\begin{array}{c}31.38 \pm 1.28^{*} \\
1.50 \pm 0.97^{*}\end{array}$ \\
\hline Treated group & $\begin{array}{l}\text { Protective } \\
\text { Therapeutic }\end{array}$ & $\begin{array}{l}6.88 \pm 1.04^{*} \\
7.99 \pm 1.13^{*}\end{array}$ & $\begin{array}{l}8.48 \pm 1.38^{* \mathrm{a}} \\
9.85 \pm 1.17^{*}\end{array}$ & $\begin{array}{l}5.02 \pm 0.78^{\mathrm{a}} \\
5.69 \pm 1.01 *\end{array}$ & $\begin{array}{l}3.46 \pm 0.67^{\mathrm{a}} \\
4.02 \pm 0.57^{*}\end{array}$ & $\begin{array}{l}11.41 \pm 1.42^{*} \\
14.27 \pm 0.91^{*}\end{array}$ \\
\hline
\end{tabular}

The presented data are mean of 20 replicates \pm SE. Data were analyzed using ANOVA one-way followed with post hoc for multiple comparisons. Appearance of * means significant difference between groups and -ve controls while appearance of letters means non-significant difference between groups that have the same letter as compared to cancer controls. $P<0.05$. GSH is glutathione, GR is glutathione reductase, GST is glutathione $\mathrm{S}$ transferase, GPx is glutathione peroxidase and CAT is catalase activities. 
Prostate cancer induction significantly suppressed glutathione reductase (GR) $(1.22 \pm 0.95 \mu \mathrm{mol} / \mathrm{mg}$ protein/min, with respect to the negative control) and vice versa, GR activity was significantly improved $(8.48 \pm 1.38$ and $9.85 \pm 1.17 \mu \mathrm{mol} / \mathrm{mg}$ protein/min for protective and therapeutic groups, respectively) in comparison with cancer control. Glutathione-S-transferase (GST) activity of prostate cancer induced animals was significantly declined by about thirteen times to reach $0.35 \pm 0.07 \mu \mathrm{mol} / \mathrm{mg}$ protein/mint. GST activity either of the protective group or of the therapeutic one was significantly induced to $5.02 \pm 0.78$ and 5.69 $\pm 1.01 \mu \mathrm{mol} / \mathrm{mg}$ protein $/ \mathrm{min}$, respectively, compared to cancer control $(0.35 \pm 0.07 \mu \mathrm{mol} / \mathrm{mg}$ protein $/ \mathrm{min})$. Glutathione peroxidase (GPx) was significantly lessened concurrence with prostate cancer induction $(0.49 \pm 0.14 \mu \mathrm{mol} / \mathrm{mg}$ protein/mint $)$ as compared to the negative control. Inversion, co-administrated vitex extract with testosterone, in protective group, protected GPx activity and remained it close to GPx activity of the negative control; 3.46 \pm 0.67 and $2.94 \pm 0.57 \mu \mathrm{mol} / \mathrm{mg}$ protein/mint, respectively. The therapeutic effect of vitex extract was successfully repaired the antioxidant system of cancer induced animals. Catalase (CAT) activity highly depleted as a response to prostate cancer induction to reach $1.50 \pm 0.97 \mu \mathrm{mol} / \mathrm{mg}$ protein $/ \mathrm{mint}$ corresponding to the negative control; $19.90 \pm 1.37 \mu \mathrm{mol} / \mathrm{mg}$ protein/mint. CAT activity was significantly elevated with vitex administration $(11.41 \pm 1.42$ and $14.27 \pm 0.91 \mu \mathrm{mol} / \mathrm{mg}$ protein/mint for protective and therapeutic groups, respectively, more than cancer control). Generally, therapeutic effect of vitex extract was better than its protective effect. It is evident from the antioxidant status recorded data that vitex berries crude extract has a crucial role in repairing oxidative stress produced in cancer animals showed as improvement in GSH concentration and induction of antioxidants enzymes activities (GR, GST, GPx and $\mathrm{CAT}$ ) that may reinforcement the vitex role in treating prostate cancer.

\section{DISCUSSION}

Prostate cancer is one of the most complex and enigmatic oncologic problems in medicine. It is highly prevalent particularly in elderly males and remains a significant health concern for men throughout the world. Current research was performed to evaluate the ability of Vitex crude extract as anti-prostate cancer. Based on its orchestral inhibitory effect on cancer risk factors including oxidative stress and inflammatory cytokines over expression, cell growth promoter $\mathrm{Na}^{+} / \mathrm{K}^{+}$ATPase, sex hormones and cancer biomarker release. As age, the concentration of effective testosterone in the blood declines, resulting increment in estrogen. Many investigations demonstrated that increasing concentration of estrogen in prostate may lead to prostate following by the cellular hyperplasia. Another hypothesis, over concentration of dihydrotestosterone (DHT) may activates cellular hyperplasia. A marked increase in the levels of prostate specific antigen (PSA) and acid phosphatase is indication on malignant transformation (Vijayakumar et al., 1995). Recent clinical trials have suggested that 5- $\alpha$ reductase inhibitors block the transformation of testosterone into DHT but, these drugs have side effects as a headache, dizziness, hypotension, fatigue, decreased libido, impotence, breast tenderness and breast magnification, and decreased sperm number. Because of these complications, naturaltherapy has been extensively researched and some phytochemicals have ability to management of BPH and Prostate cancer (Shukla and Kolhapure, 2004). prostate cells are susceptible to androgens either it is normal or malignant. Testicles and adrenal glands are the major sources of androgens production. Therapeutic based researches have indicated the preventive role of 5- $\alpha$ reductase inhibitors in consumption of testosterone to dihydrotestosterone (DHT). Synthetic drugs targeted this mechanism have a lot of adverse side effects like impotence, breast enlargement, headache, hypotension, declined libido, breast tenderness and decreased sperm count (Shukla and Kolhapure, 2004). According to these facts, searching for natural anti-androgen can avoid these massive side effects and have to be beneficial in this concern. It was proved in clinical trials that prostate cancer always accompanied with significant depletion in testosterone level which consumed in conversion of testosterone into DHA, more potent form of testosterone, that increases the cancer cell growth and hyperplasia in benign prostate hyperplasia (BPH) patient. Based on this fact, anti-androgen compounds play an important role in prostate cancer manipulation through this toxic effect on cancer cell growth (Goldenberg et al., 2009).

Results of this work clearly indicated that vitex berries crude extract has 5-a reductase inhibitory action, anti-androgen effect, that may lead to decrease in DHT known as promoter of cellular hyperplasia. This anti-androgen effect increases the level of testosterone in blood. On the other hand, vitex is rich in estrogen like compounds, phytoestrogen, which bounded to estrogen receptors and produces the same effect of estrogen (Ahangarpour et al., 2016). Enhancing of estrogen level progressively led to suppression in leutinizing hormone release from hypothalamus, feedback mechanism, that decreases testosterone production (Nelles et al., 2011). This two opposite effects produced controlled increment in testosterone in cancer animals treated with vitex extract. $\mathrm{Na}^{+} / \mathrm{K}^{+}$ATPase is a commonly stated in plasma membrane transportation system. $\mathrm{Na}$ and $\mathrm{K}$ gradient transporting system is maintained by Its role. $\mathrm{Na}^{+} / \mathrm{K}^{+}$ ATPase is responsible for adjustment of $\mathrm{K}$ and $\mathrm{Na}$ uptake at the expense of ATP. The $\mathrm{Na}^{+}$gradient has many essential functions in cells as active uptake of hexose sugars, amino acids and nucleosides, electrical membrane potential changes mediated by voltage-activated ion channels, and $\mathrm{Ca}^{+2}$ uptake. To keep cell maintenance, $\mathrm{Na}^{+} / \mathrm{K}^{+}$ATPase controls ionic gradients. The ratio between $\mathrm{Na}^{+}$and $\mathrm{K}^{+}$adjusted intracellular $\mathrm{pH}$ that regulates absorption and excretion in epithelial cells (Mobasheri et al., 2003). $\mathrm{Na}^{+} / \mathrm{K}^{+}$ATPase is a transmembrane protein complex consisted of double isoform combinations of a-catalytic, $\beta$ regulatory and $\gamma$-modulatory subunits working as a key energy driver protecting ionic and osmotic balance in cells. Prostate gland is responsible for anion citrate synthesis and excretion which depends on accumulation of aspartate and glucose as a part of 
sufficient role of $\mathrm{Na}^{+} / \mathrm{K}^{+}$ATPase transportation system in prostate epithelial cells to keep rapid supply of citrate anion. In the presence of $\mathrm{Na}^{+} / \mathrm{K}^{+}$ATPase inhibitors, the accumulation of asparate is fluctuated followed with insufficient citrate production that consequently suppress prostate epithelial cell metabolism and growth (Mobasheri et al., 2003). Moreover, the $\alpha-1$ subunit is Recognizedby its essential function in cell/cell adhesion as well as cell/matrix interaction. Recently, it was confirmed an essential function of $\mathrm{Na}^{+} / \mathrm{K}^{+}$ATPase $\alpha-1$ subunit in organization of cellular kinase activity via its interaction with Proto-oncogene tyrosineprotein kinase Src (c-Src) in the plasma membrane (Tian et al., 2006). Therefore, it was suggesting that the diminishing in the plasma membrane $\alpha-\alpha-1-\mathrm{Na}^{+} / \mathrm{K}^{+}$ATPase might influence the development of tumor in diverse ways. First, the down-regulation of $1-\mathrm{Na}^{+} / \mathrm{K}^{+}$ATPase could reduce the ability of $\mathrm{Na}^{+} / \mathrm{K}^{+}$ATPase to interact resulting block cellular Src. This lead to increase basal Src and Non-receptor protein kinases FAK ability and then activate epithelial cell proliferation, migration, and invasion (Irby et al., 2000). Consistently, these results observed that metastatic prostate cancer cells are extremely susceptible to the addendum of the $\mathrm{Na}^{+} / \mathrm{K}^{+}$ATPase $\alpha-1$ mimetics. Second, a reduction in the $\alpha-1-$ $\mathrm{Na}^{+} / \mathrm{K}^{+}$ATPase plasma membrane weakens the capability of cells to supply a counter regulation of Src and other growth-regulators pathways, particularly in cellular structures such as tight junctions and adhesions where the $\mathrm{Na}^{+} / \mathrm{K}^{+}$ATPase is highly concentrated in normal epithelial cells. This might happen when cellular Src is induced by steroid hormone/receptor interaction or other factors like elevated activity of human epidermal growth factor receptor (Irby et al., 2000). Finally, raises Src activity because of the downregulation of $\alpha-1$ could induces VEGF production and then activate angiogenesis. Therefore, using $\mathrm{Na}^{+} / \mathrm{K}^{+}$ATPase inhibitors in prostate cancer cell growth became one of the most abundant therapeutics. In this study vitex extract decreased $\mathrm{Na}^{+} / \mathrm{K}^{+}$ATPase when used as protective or therapeutic agents. It is evident from these results the potential role of vitex crude extract in controlling tumor growth through its inhibitory effect on $\mathrm{Na}^{+} / \mathrm{K}^{+}$ATPase. Our findings may explain the role of vitex extract in stopping the development of prostate cancer cells where a great amount of $\mathrm{Na}^{+} / \mathrm{K}^{+}$ATPase is composed in the plasma membrane and may stimulate apoptosis blocks cell growth, and reduces tumor angiogenesis which increase the chance of using vitex crude extract in developing novel anticancer therapeutics likely related to the Src inhibitory action pathway.

Prostate specific antigen is a member of serine proteases. It is a prostate product founded in normal and cancer cells which secreted in seminal fluid from gel character (Lilja, 1985). Prostate gland saves PSA in the gland tissue and incorporate low amounts in the circulating way. The circulated PSA presented in two forms, free and complexed one. The total PSA amounts divided into two portions, $5-35 \%$ free and $65-95 \%$ bounded to inhibitors of protease, which doesn't have catalytic effect in blood (Piironen $e t$ al., 2001). The free PSA existed in three forms, benign PSA (BPSA), intact PSA (iPSA) and proPSA that produced in a significant level in prostate cancer patient (PC) (Nogueira et al.,
2009). The prostate impairment resulted significant increments in serum which allow entering PSA into circulation, therefore, it appears in both prostatic cancer and prostate hyperplasia and can be monitored through treatments (Wei et al., 1997). (Vijayakumar et al.,1995). It is evident from presented work results that, vitex berries crude extract significantly decreased serum PSA in both protective and therapeutic treatments and the potent suppressor effect on PSA level was recorded with therapeutic treatment. Prostate specific antigen is a member of serine proteases. It is aprostate product founded in normal and cancer cells which secreted inseminal fluid from gel character. Prostate gland saves PSA in thegland tissue and incorporate low amounts in the circulating way. The circulated PSA presented in two forms, free and complexed one. The total PSA amounts divided into two portions, $5-35 \%$ free and $65-95 \%$ bounded to inhibitors of protease which doesn't have catalytic effect in blood (Piironen et al., 2001). The free PSA existed in three forms, benign PSA (BPSA), intact PSA (iPSA) and proPSA that produced in a significant levels in prostate cancer patient (PC) (Nogueira et al., 2009). The prostate impairment resulted significant increments in serum which allow entering PSA into circulation, therefore, it appears in both prostatic cancer and prostate hyperplasia and can be monitored through treatments. Accordingly, PSA has been commonly detected as prostate cancer in serum. Prostate specific antigen is highly induced as androgen response. Based on this idea, PSA level is decreased by 50\% in patient used 5- $\alpha$ reductase agent like finasteride which means PSA should to be duplicated without these inhibitors (Marks et al., 2006). At this point of view, a significant reduction in PSA level is associated with the reduction in prostate hyperplasia and cancer treatment with reductase inhibitors and with anti-inflammatory agent therapeutics. Not similar to those expected, PSA level in serum is not correlated with leutinizing hormone, and rostenedione and testosterone but is mostly related to prolactin level as it was recorded in rat experiments. It is evident from presented work results that, vitex berries crude extract significantly decreased serum PSA in both protective and therapeutic treatments and the potent suppressor effect on PSA level was recorded with therapeutic treatment. Cyclooxygenases (COX) enzymes play as switch key in arachidonic acid conversion into PGH2, immediate substrate, to start biosynthesis of a series thromboxane and cell specific prostaglandin. However, Prostaglandins responsible for many crucial roles in involved in cell biological pathways, including immune function regulation, developing of kidney, maintenance of reproductive processes, and integrity of gastrointestinal. They are two isoforms of cyclooxygenases differ in their expression pattern. Although COX-1 is released in most tissues and responsible for cell maintenance through production of cytoprotective prostaglandins, $\mathrm{COX}-2$ is the absence cyclooxygenase member but it is induced by stimulation of some physiological processes (Simmons et al., 2004). Many researches demonstrated that, secretion of COX-2 is induced in both epithelial and stromal tumors components. Abundant increments in COX- 2 is founded in epithelial adenocarcinoma, which promote growth of 
tumor by production of prostaglandins. COX-2 is involved in all tumor progression, over expression of COX-2 induced transforming growth factor- $\beta$ and hyperproliferation led to adenoma and then induction of P53, used as tumor biomarker in carcinoma. These events with additional changes led to invasion of metastasis (Christopher et al., 1999). Therefore, this mode of action is progressively targeted and is involved in such clinical trials to find promising anti-cancer therapeutics in managing cancers. Anti-cancer therapeutics targeted COX-2 inhibition is considered as promising agents in cancer management. Unfortunately, using COX-2 inhibitors led to many negative adverse effects on health. Therefore, selective non-steroidal antiinflammatory drugs is considered as valuable targeted agents which can decrease release of COX-2 and control progression of cancer. Our finding concluded that administration of vitex berries extract showed reduction on COX-2 concurrence with increment in COX-1.

Reactive oxygen species (ROS) can cause mutation by damaging genetic molecules and cell division. These reactive molecules may interrupt cell signaling and growth or attach DNA to induce DNA damage which is main risk factor for cancer. On the other hand, ROS induce inflammatory response and aggregate inflammatory cascade to increase the evidence of cancer inside in inflamed tissues. Based on this idea, antioxidants can play main role in depression of tumor evidence or its progression through suppression of premalignant lesions and inhibition of cancer development (Mahmoud et al., 2016).Vitex extract in this research ameliorated antioxidant status and recovering oxidative stress occurred concurrence prostate cancer. Vitex extract elevated activities of antioxidant enzymes like GR, GST, GPx and CAT as well as glutathione concentration.

Taking an overview on this work, obtained results may prove the potential role of Vitex agnus-castus berries crude extract as preventive agent to prohibit benign prostate hyperplasia progression into prostate cancer as well as vitex therapeutic potential against prostate cancer in an orchestral approach including inhibition of $\mathrm{Na}^{+} / \mathrm{K}^{+}$ATPase, 5-a reductase and selective inhibitory effect on COX-2 with its ameliorative effect on body oxidant status that was exhibited in withdrawal of carcinoembryonic antigen level and prostate specific antigen level estimated in animal sera. These findings support incorporation of Vitex agnus-castus berries crude extract in advanced clinical trials for treating herbal prostate cancer therapeutic as an alternative approach medication.

\section{CONCLUSION}

In conclusion, our in vivo results clearly demonstrated that Vitex agnus-castus berries crude extract could treat prostate cancer with induction of apoptosis without any signs of toxicity also it can reduce the relative risk to prostate cancer when it used in benign prostate hyperplasia, preventive agent. Our findings and the fact that most prostate cancers are initially androgen-dependent suggest that Vitex agnus-castus berries crude extract should introduced in advanced clinical trials for herbal manipulation.

\section{ACKNOWLEDGMENTS}

Financial support and sponsorship: This work was sponsored by National Research Centre, Egypt, through the project No 10010103 under title" New drug discovery for breast and prostate cancers from medicinal plants cultivated under Egyptian condition and polysaccharides from natural sources, 2013-2016". Project Principle investigator, Dr. Abeer Y. Ibrahim.

Conflict of Interests: There are no conflicts of interest.

\section{REFERENCES}

Ahangarpour A, Najimi SA, Farbood Y. Effects of Vitex agnuscastus fruit on sex hormones and antioxidant indices in a D-galactoseinduced aging female mouse model. J. Chinese Med. Assoc. 2016; 79: 589-596.

Ahmed I, Sansom O, Leung H. Advances in mouse models of prostate cancer. Expert Rev Mol Med 2008; 10: e16.

Alevizopoulos K, Calogeropoulou T, Lang F, Stournaras C. $\mathrm{Na}^{+} / \mathrm{K}^{+}$ATPase inhibitors in cancer. Curr. Drug. Targets. 2014; 15: 9881000 .

Allain CC, Poon LS, Chan CS, Richand W, Paul CF. Enzymatic determination of total cholesterol. Clin. Chem. 1974; 20: 470-474.

American Cancer Society. Cancer Facts \& Figures for African Americans 2013-2014. Atlanta, Ga: American Cancer Society; 2013.

American Joint Committee on Cancer. Prostate. In: AJCC Cancer Staging Manual. 7th ed. New York, NY: Springer; 2010: 457-464.

Beers RF, Sizer IW. A spectrophotometric method for measuring the breakdown of $\mathrm{H} 2 \mathrm{O} 2$ by catalase. J. Biol. Chem. 1952; 195:133-140.

Blume-Peytavi U, Whiting DA, Trüeb RM. Hair Growth and Disorders. Springer Science \& Business Media. 2008; 368-370.

Bosland MC. Animal model for the study of prostate carcinogenesis. J. Cell Biochem. Suppl. 1992; 16: 89-98.

Bruce RD. An up-and-down procedure for acute toxicity testing. Fundam Appl. Toxicol. 1985; 5: 151-157.

Chen D, Song M, Mohamad O, Yu SP. Inhibition of $\mathrm{Na}+/ \mathrm{K}+$ ATPase induces hybrid cell death and enhanced sensitivity to chemotherapy in human glioblastoma cells. BMC Cancer 2014; 14: 716.

Chopin Lucks, B. The Vitex Anthology: Explorations in Menopausal Balance Proceedings of the 4th Aromatherapy Conference on the Therapeutic Uses of Essential Oils. San Francisco, Nov. 10-12, 2000b. Pacific Institute of Aromatherapy 2000.

Chopin Lucks, B. Vitex agnus-castus essential oil and menopausal balance: a self-care survey. Complement Ther. Nurs. Midwifery 2000a; 8: 148-154.

Christopher S Williams, Moss Mann, Raymond N DuBois. The role of cyclooxygenases in inflammation, cancer, and development. Oncogene 1999; 18: 7908 -7916.

El-Menshawi BS, Fayad W, Mahmoud K, El-Hallouty SM, ElManawaty M, Olofsson MH, Linder S. Screening of natural products for Therapeutic activity against solid tumors. Indian J. Exp. Biol. 2010; 48: 258-264.

Estadella D, Oyama LM, Damaso AR, Ribeiro EB, Claudia M, Oller DN. Effect of palatable Hyperlipidemic diet on lipid metabolism of sedentary and exercised rats. Nutrition. 2004; 20: 218-224.

Faulkner WR, King JW. Renal function. In: Teitz N (ed) Fundamentals of clinical chemistry. W.B. Saunders, Philadelphia, 1976; 975-1014

Garg R, Kumar R, Nathiya D, Goshain O, V Trivedi V, Sharma AK, Murti K. Comparative Acute Toxicity Studies of Selected Indigenous Herbal Plants in Swiss Albino Mice. IOSR Journal of Pharmacy and Biological Sciences 2016; 11 (3): 20-27

Ghosh MN. Satistical Analysis, Fundamentals of Experimental Pharmacology. (Calcutta: Scientific Book Agency; 1984). 189-190. 
Gochman N, Schmitz JM. Automated determination of uric acid with use of auricase-peroxidase system. Clin. Chem. 1971; 17: 11541159.

Goetz P. Phytotherapy of benign prostatic hyperplasia. Phytotherapie 2009; 7: 275-278.

Goldberg DM, Spooner RJ. In: Bargemen HV (ed) Methods of enzymatic analysis. Verlag Chemie, Weinheim, 1983; 3:258265 .

Goldenberg L, So A, Fleshner N, Rendon R, Drachenberg D, Elhilali M. The role of 5-alpha reductase inhibitors in prostate pathophysiology: Is there an additional advantage to inhibition of type 1 isoenzyme? Can. Urol. Assoc. J. 2009; 3: S109-114.

Griffith OW. Determination of glutathione and glutathione disulfide using glutathione reductase and 2-vinyl pyridine. Anal. Biochem. 1980; 106:207-212.

Habig WH, Pabst MI, Jacoby WB. Glutathione-S-transferase. J BiolChem 1974; 249:7130-7139. 1964: p 181.

Henry RJ. Clinical chemistry. Harper and Row, New York,

Irby RB, Yeatman TJ. Role of Src expression and activation in human cancer. Oncogene 2000; 19: 5636-5642.

Iweala EEJ, Ogidigo JO. Prostate specific antigen, antioxidant and hematological parameters in prostatic rats fed Solanum macrocarpon L. leaves. Asian J. Biol. Sci. 2015; 8: 30-41.

Juang GD, Hwang TIS, Wang YH. Metastatic prostate cancer with elevated serum levels of CEA and CA19-9, Urol. Sci. 2014; 25: 2830.

Klap J, Schmid M, Loughlin KR. The Relationship between Total Testosterone Levels and Prostate Cancer: A Review of the Continuing Controversy. J Urol 2015; 193: 403-414.

Lilja H. A kallikrein-like serine protease in prostatic fluid cleaves the predominant seminal vesicle protein. J. Clin. Invest. 1985; 76: 1899-1903.

Mahmoud MG, Mohamed SS, Ibrahim AY, El Awady ME, Youness ER. Exopolysaccharide produced by paenibacillus lactes NRC1: Its characterization and anti-inflammatory activity via cyclooxygenases inhibitory activity and modulation of inflammation related cytokines. Der Pharma Chemica. 2016; 8:16-26.

Marks LS, Andriole GL, Fitzpatrick JM, Schulman CC, Roehrborn CG. The interpretation of serum prostate specific antigen in men receiving 5-alpha-reductase inhibitors: a review and clinical recommendations. J. Urol. 2006; 176: 868-74.

Merz PG, Gorkow C, Schrödter A, Rietbrock S, Sieder C, Loew D, Dericks-Tan JS, Taubert HD. The effects of a special Agnus castus extract (BP1095E1) on prolactin secretion in healthy male subjects. Exp Clin Endocrin Diabet 1996; 104: 447-53.

Mobasheri A, Pestov NB, Papanicolaou S, Kajee R, CózarCastellano I, AVila et al. Expression and cellular localization of $\mathrm{Na}, \mathrm{K}-$ ATPase isoforms in the rat ventral prostate. Bju international 2003; 92: $793-802$.

Morgentaler A, Rhoden E. Prevalence of prostate cancer among hypogonadal men with prostate-specific antigen levels of $4.0 \mathrm{Ng} / \mathrm{Ml}$ or less. Urology 2006; 68: 1263-1267.

Mosmann T. Rapid colorimetric assays for cellular growth and survival: Application to proliferation and cytotoxicity assays. J Immunol Methods. 1983; 65: 55-63.

Nelles JL, Hu WY, Prins GS. Estrogen action and prostate cancer. Expert. Rev. Endocrinol. Metab. 2011; 6, 437-451.
Nogueira L, Corradi R, Eastham JA. Prostatic specific antigen for prostate cancer detection. International Braz. J. Urol. 2009; 35: 521 531.

Paglia DE, Valentine WN. Studies on the quantitative and qualitative characterization of erythrocyte glutathione peroxidase. J. Lab. Clin. Med. 1967; 70:158-169.

Piironen T, Nurmi M, Irjala K, Heinonen O, Lilja H, Lövgren T, et al:: Measurement of circulating forms of prostate-specific antigen in whole blood immediately after venipuncture: implications for point-ofcare testing. Clin. Chem. 2001; 47: 703-11.

Pruthi RS, Derksen E, Gaston K. Cyclooxygenase-2 as a potential target in the prevention and treatment of genitourinary tumors: a review. J. Urol. 2003; 169: 2352-2359.

Reitman S, Frankel SA. Colorimetric method for the determination of serum glutamic oxaloacetic and glutamic pyruvic transaminases. Am. J. Clin. Pathol.1957; 28: 56-63.

Shukla K, Kolhapure SA. Evaluating the efficacy and safety of Himplasia (PC-27) in the medical management of benign hyperplasia. Indian J. Clin. Pract. 2004: 14: 31-36.

Simmons DL, Botting RM, Hla T. Cyclooxygenase isozymes: the biology of prostaglandin synthesis and inhibition. Pharmacol. Rev. 2004; 56: 387-437.

Tabacco A, Meiathini F, Moda E, Tarli P. Simplified enzymic/colorimetric serum urea nitrogen determination. Clin. Chem. 1979; 25: 336-337.

Thabrew MI, Hughes RD, McFarlane IG. Screening of hepatoprotective plant components using a HepG2 cell cytotoxicity assay. J Pharm Pharmacol. 1997; 49: 1132-5.

Tian J, Cai T, Yuan Z, Wang H, Liu L, Haas, et al. Binding of $\mathrm{Src}$ to $\mathrm{Na} / \mathrm{K}-\mathrm{ATPase}$ forms a functional signaling complex. Mol. Biol. Cell. 2006; 17: 317-326.

Vijayakumar S, Quadri SF, Dong L, Ignacio L, Kathuria IN, Sutton et al. Results of a study to correlate serum prostate specific antigen and reproductive hormone levels in patients with localized prostate cancer. J. Nat. Med. Assoc. 1995; 87: 813-819.

Vijayakumar S, Quadri SF, Dong L, Ignacio L, Kathuria IN, Sutton H, Halpern H. Results of a study to correlate serum prostate specific antigen and reproductive hormone levels in patients with localized prostate cancer. J Natl Med Assoc, 87: 813-819.

Wei C, Willis RA, Tilton BR, Looney RJ, Lord EM, Barth, et $a l$. Tissue-specific expression of the human prostate-specific antigen gene in transgenic mice: Implications for tolerance and immunotherapy. Proc. Natl. Acad. Sci. USA 1997; 94: 6369-6374.

\section{How to cite this article:}

Ibrahim AY, El-Newary SA, Youness ER, Ibrahim AM, El Kashak WA. Protective and therapeutic effect of Vitex agnus-castus against prostate cancer in rat. J App Pharm Sci, 2017; 7 (12): 133-143. 